\title{
Animasi sebagai Media Pendidikan Karakter Berbasis Tri Kaya Parisudha untuk Anak-Anak
}

\author{
I Gusti Agung Rangga Lawe'1, Irfansyah ${ }^{2}$, dan Hafiz Aziz Ahmad ${ }^{3}$ \\ ${ }^{1}$ Magister Desain, Fakultas Seni Rupa dan Desain, Institut Teknologi Bandung \\ ${ }^{2,3}$ Fakultas Seni Rupa dan Desain, Institut Teknologi Bandung
}

'agunglawe@gmail.com

\begin{abstract}
Pendidikan karakter sangat penting untuk diberikan pada anak sejak dini, terutama saat ia berada dalam fase imitasi, di mana anak belajar meniru perangai seperti cara bicara dan cara bersikap yang diambil dari model yang diteladani. Meniru dengan keteladanan mengajarkan anak untuk mengembangkan moral, sosial dan spiritual mereka. Salah satu landasan pendidikan karakter dalam Hindu adalah ajaran Tri Kaya Parisudha, yang terdiri dari Manacika, Wacika, dan Kayika. Ajaran ini sangat penting untuk dipahami dan diamalkan oleh anak di kehidupan sehari-hari, karena akan membentuk sifat integritas dan jati dirinya. Keselarasan antara pikiran, ucapan, dan tindakan agar selalu berada di jalan yang baik dan benar dalam Tri Kaya Parisudha dapat disampaikan menggunakan pendekatan keteladanan, yaitu proses meniru perilaku yang diperagakan oleh model/ idola yang disukai mereka. Di era modern, penerapan pendidikan karakter bisa dilakukan dengan bantuan media eksternal seperti animasi. Konsep pendidikan karakter dikemas lewat tokoh animasi dan dapat dijadikan model/idola oleh anak untuk ditiru. Selain itu, nilai yang terkandung lewat cerita di animasi juga dapat terbawa sampai anak tumbuh dewasa, dan dijadikan referensi olehnya saat dibutuhkan. Adanya ikatan emosional anak pada karakter animasi menyebabkan anak meniru gaya/gerak karakter tersebut, hingga turut merasakan apa yang dirasakan karakter itu. Selain itu, cerita dalam animasi juga memberikan pengalaman baru bagi anak untuk dijadikan pembelajaran dalam pembentukkan karakternya. Sebagai media pembelajaran, animasi dapat menunjang aspek kognitif anak dengan cara mengingat apa yang ia dapat di animasi tersebut, untuk kemudian ditiru agar dapat membentuk karakter mereka.
\end{abstract}

Kata kunci : Pendidikan karakter, tri kaya parisudha, animasi

\section{Animation as a Character Education Media Based on Tri Kaya Parisudha for Children}

Character education is crucial to be given to children from early age, especially when they are in the imitation phase, where children learn to imitate mannerisms such as ways of speaking and behaving which are taken by imitating the model. It teaches children to develop their moral, social and spiritual. One of character education principle in Hinduism is teaching Tri Kaya Parisudha, which consists of Manacika, Wacika and Kayika. This teaching is crucial to be understood and practiced by children in daily life, because it will form their integrity and identity. The harmony between thought, word, and action to always be on the good and right path in Tri Kaya Parisudha can be conveyed by using exemplary approach, which is the process of imitating behavior exhibited by the model/idol who they like. In modern era, the application of character education can be done by helping from external media such as animation. The concept of character education packaged through story in animation can be used as model/idol by children to imitate. Moreover, the value contained through stories in animation also can be carried over until children are growing up, and going to be their reference when needed. The existence of children emotional bond to the animated character causes children to imitate the character's style/movement, thus they can feel what the character feels. In addition, the story in animation also provides new experiences for children to be used as learning in forming their character. As a learning media, animation can be supported the cognitive aspects of children by remembering what they caught in its animation, then imitated it in order to form their character.

Keywords : Character education, tri kaya parisudha, animation 


\section{PENDAHULUAN}

Karakter sebuah bangsa dapat tercermin dari karakter para penduduknya, dan pembentukkan karakter sudah seharusnya dimulai sejak dalam masa anak-anak. Apa yang anak dapatkan dalam masa usia emas (golden age) sangat menentukan karakternya kelak saat ia dewasa. Ketika anak tidak mendapatkan pendidikan karakter yang cukup, maka moral dan etika mereka akan menjadi buruk. Karakter yang buruk akan menghasilkan perilaku yang buruk bagi anak. Hal tersebut dapat terlihat dalam data yang dihimpun oleh Komisi Perlindungan Anak Indonesia (KPAI) yang mencatat terjadinya beberapa kasus kekerasan anak pada awal tahun 2019. KPAI menyebutkan sekitar 67\% kasus terjadi di jenjang sekolah dasar, dan beberapa di antaranya adalah kasus bullying, pengeroyokan, hingga kasus anak bully guru (Maradewa, 2019). Perilaku seperti itu merupakan sedikit contoh dari apa yang anak-anak tiru.

Usia anak-anak merupakan masa pembentukkan karakter yang krusial, sehingga diperlukan pengawasan dan pembimbingan agar mereka memiliki karakter yang baik. Di masa ini anak akan melakukan proses imitasi, yaitu proses di mana mereka akan meniru apa yang dilihat dan didengar. Ketika anak ingin melakukan sesuatu (baik atau buruk), mereka akan memulai dengan melihat, mengamati, dan memperhatikan, lalu diikuti oleh meniru, mengingat, dan menyimpannya di benak mereka, untuk kemudian dikeluarkan lagi sesuai dengan apa yang mereka ingat (Dahlia dkk., 2017). Proses meniru merupakan langkah awal bagi anak dalam membentuk karakternya. Ada banyak sumber rujukan yang bisa ditiru oleh anak, mulai dari keluarga, pergaulan sehari-hari, hingga hal-hal yang mereka konsumsi dari media eksternal.

Media eksternal yang sering dikonsumsi oleh anak saat ini adalah media elektronik seperti smartphone atau tablet pintar. Berkat adanya akses internet di media elektronik tersebut, memungkinkan anak untuk terhubung dengan berbagai konten-konten yang ada di dalamnya. Apabila tidak diawasi, kegiatan ini akan mengganggu kemampuan emosional anak, karena mereka akan meniru apa yang sering mereka lihat di media tersebut, apalagi jika hal itu dilakukan secara berlebihan dan terus-menerus (Suhana, 2017). Maka dari itu, anak sangat perlu diberikan konten yang positif untuk mereka tiru. Salah satu konten yang paling sering diakses oleh anak-anak di media seperti smartphone atau tablet pintar adalah Youtube. Di sana, anakanak bisa mengakses berbagai jenis video yang mereka sukai, seperti video animasi.

Video animasi untuk anak-anak yang populer di YouTube biasanya berisi cerita atau dongeng. Selain sebagai media hiburan, animasi juga dapat dijadikan sebagai media untuk menyampaikan ilmu pengetahuan. Sifat animasi yang imajinatif akan memudahkan dalam menyampaikan pen- getahuan yang sifatnya abstrak. Dari sana timbul peluang untuk menggunakan animasi sebagai media dalam menyampaikan pendidikan karakter yang menarik untuk anak. Membentuk karakter anak merupakan proses yang panjang, dan tidak dapat langsung mengubah karakter mereka. Lewat animasi, setidaknya anak dapat mengingat dan memahami materi pendidikan karakter yang disampaikan. Dari berbagai unsur animasi, unsur cerita dan penokohan merupakan aspek yang dapat dimanfaatkan dalam mengemas materi pendidikan karakter. Ada banyak model pendekatan pendidikan karakter yang bisa digunakan, salah satunya yang terdapat di dalam ajaran agama Hindu adalah "Tri Kaya Parisudha".

Tri Kaya Parisudha merupakan landasan etika yang tertinggi dari ajaran Tata Susila Hindu, yang kemudian dijadikan sebagai pedoman dalam pembentukkan karakter manusia (Singer, 2015). Tri Kaya Parisudha berarti tiga perilaku yang disucikan, terdiri dari Manacika (berpikir yang baik dan benar), Wacika (berkata yang baik dan benar), dan Kayika (berbuat yang baik dan benar). Ironisnya, pengetahuan akan ajaran ini kian memudar di kalangan anak-anak Hindu terutama yang tinggal di luar pulau Bali. Agar pendidikan karakter berlandaskan Tri Kaya Parisudha dapat dengan mudah diterima oleh anak-anak, media seperti animasi bisa digunakan sebagai sarana penyampaiannya. Oleh karena itu, perlunya dikaji bagaimana menyampaikan konten pendidikan karakter berbasis Tri Kaya Parisudha ke dalam animasi.

\section{PEMBAHASAN}

\section{Perkembangan Anak dan Perilaku Meniru}

Pendidikan karakter sangat penting untuk diberikan pada setiap manusia, guna menghasilkan manusia-manusia yang bijaksana, bermoral dan beretika baik. Pengenalan terhadap pendidikan karakter dapat dilakukan sejak kecil, yaitu saat manusia dalam tahap anak-anak. Menurut Hurlock dkk. (1990), berdasarkan tahapan dalam rentang kehidupan masa anak-anak dibagi menjadi dua, yaitu awal masa anak-anak yang biasa dikenal sebagai usia prasekolah (2-6 tahun) dan akhir masa anak-anak (612 tahun) yang lebih dikenal sebagai usia sekolah dasar (Hurlock dkk., 1990). Anak dalam masa akhir anak-anak dianggap lebih siap secara fisik dan psikologis untuk menerima pembelajaran yang dapat mengubah sikap, nilai, dan perilaku mereka ketimbang anak dalam masa awal anak-anak. Selain itu, Piaget (1970) dalam Hurlock dkk. (1990) berpendapat bahwa anak-anak di masa ini memasuki tahap operasi konkret dalam berpikir, di mana konsep yang samar dan tidak jelas pada awal masa anak-anak, kini menjadi lebih konkret dan tertentu (Hurlock dkk., 1990). Berdasarkan fase perkembangannya, anak-anak di usia ini memasuki masa imitasi, di mana mereka akan meniru apa yang mereka lihat dan dengar sebagai cara dalam membentuk karakter mereka. 


\section{Perilaku Meniru/Imitasi pada Anak}

Dalam masa anak-anak, karakter dan sikap mereka sangat dipengaruhi oleh lingkungan di sekitarnya. Hal tersebut disebabkan oleh perilaku meniru/imitasi yang dilakukan oleh anak-anak. Bandura (1963) mengatakan bahwa proses meniru merupakan cara anak mempelajari perangai (mannerism), cara bicara (voice inflections), dan cara bersikap (attitudes) secara lebih alamiah (Bandura, 1963). Proses meniru berlangsung karena anak-anak akan mengobservasi sumber rujukan yang disebut sebagai model. Dalam proses pembelajaran dengan observasi, Bandura (1961) dalam Nabavi (2012) menyebutkan ada tiga model dasar, yaitu live model (yang memerankan/menunjukkan perilaku secara langsung), verbal instructional model (yang memberikan penjelasan/deskripsi tentang suatu perilaku), dan symbolic model (yang melibatkan karakter nyata/fiksi dalam menunjukkan perilaku di buku, televisi, atau media online) (Nabavi, 2012). Ketiga model dasar tersebut sangat berpengaruh ketika anak hendak melakukan proses imitasi. Imitasi sangat penting bagi perkembangan karakter anak, karena secara langsung akan mempengaruhi bagaimana ia bersikap dan berperilaku ketika ia semakin tumbuh dewasa. Menurut Rakhmawati (2015), imitasi merupakan proses meniru anak setelah ia memperhatikan sikap, perkataan, hingga perilaku orang lain yang dianggapnya berkesan, menyenangkan, atau menarik bagi dirinya (Rakhmawati, 2015). Saat anak yang mengidolakan suatu tokoh/karakter yang menarik hatinya, di sana ia belajar untuk menirukan apa saja yang menurutnya berkesan dari tokoh/karakter tersebut.

\section{Perilaku Meniru sebagai Proses Pembelajaran}

Perilaku meniru lewat keteladanan (modeling) sangat penting dalam proses pembelajaran, karena anak dapat belajar banyak hal hanya dengan meniru idola/model yang mereka sukai. Akbar (2019) berpendapat bahwa meniru dengan keteladanan merupakan salah satu cara yang baik untuk diterapkan dalam pendidikan karakter anak, karena dirasa sangat efektif dalam pengembangan moral, sosial, dan spiritual anak (Akbar, 2019). Selain itu, apa yang mereka tiru dalam masa anak-anak akan tertanam di ingatan mereka, untuk kemudian ditarik kembali seiring bertambahnya usia. Menurut Labiadh dan Ramanantsoa (2014) proses menarik/mengingat kembali ini dipengaruhi oleh sifat perilaku (transitif atau intransitif), kebergunaan terhadap rangkaian perilaku (diperlukan atau tidak diperlukan), serta usia anak tersebut (Labiadh \& Ramanantsoa, 2014). Tahap penarikan kembali ini merupakan bagian dari aspek mengingat (remembering), yaitu aspek dasar dalam tahapan pembelajaran di taksonomi Bloom. Ketika anak mengingat apa yang ia tiru, ia akan berusaha untuk mengulang kembali hal tersebut di kehidupannya sehari-hari, sehingga terciptalah perilaku/sikap dari hasil menirunya. Oleh karena itu, anak perlu dibekali dengan pendidikan karakter yang cukup, agar ia dapat memilah mana yang harus ia tiru dan mana yang harus ia hindari.

\section{Pendidikan Karakter Anak}

Setiap manusia pastinya memiliki karakter yang berbeda antara satu dengan yang lain, dan karakter itulah yang membuat setiap manusia itu unik, punya ciri khas tertentu. Biarpun sebagian menganggap bahwa karakter itu adalah bawaan lahir, namun karakter juga bisa dibentuk. Tujuan dari pembentukan karakter adalah mengarahkan karakter manusia menuju ke arah positif, dan menghindarkannya dari bentuk-bentuk karakter yang negatif. Jelantik (2016) mendefinisikan karakter sebagai kepribadian, watak, atau nilai khas seseorang yang tercipta berkat penghayatan dari kegiatannya dalam kehidupan sehari-hari (Jelantik, 2016). Salah satu cara dalam membentuk karakter manusia adalah melalui pendidikan karakter. Lickona (1991) dalam Sudrajat (2011) mendefinisikan pendidikan karakter sebagai suatu usaha yang dilakukan secara sengaja untuk membantu manusia sampai ia mampu dalam memahami, memperhatikan, serta melakukan berbagai nilai etika yang utama (Sudrajat, 2011). Nilai-nilai tersebut dikembangkan dari pelaksanaan proses moral knowing (pengetahuan tentang langkah-langkah yang harus ditempuh dalam mencapai tujuan pendidikan moral), moral feeling (pembahasan sisi emosional dalam pendidikan karakter), dan moral action (hasil yang didapat dari pengamalan moral knowing dan moral feeling). Ketiga proses tersebut dapat dipicu dengan menerapkan berbagai pendekatan dalam menyampaikan pendidikan karakter.

\section{Pendekatan Keteladanan/Imitasi dalam Pendidikan Karakter}

Ada banyak pendekatan yang dapat digunakan untuk menyampaikan pendidikan karakter pada anak-anak. Zuchdi (2010) berpendapat bahwa pendekatan komprehensif seperti keteladanan (modeling), pengembangan keterampilan (skill building), penanaman nilai (inculcation) serta fasilitasi (facilitation) dapat dijadikan sebagai pendekatan pendidikan karakter (Zuchdi, 2010). Pendekatan melalui keteladanan adalah salah satu cara dalam mengajarkan pendidikan karakter pada anak-anak. Menurut Sitompul (2016), keteladanan adalah sebuah proses asimilasi (mencontoh) yang dilakukan oleh anak dengan cara meniru (imitasi) perilaku yang dilakukan/diperagakan oleh idolanya. Keteladanan dapat dipicu oleh rasa kagum anak pada model/idola, baik dari kepintarannya, kemampuannya, dan lain-lain, sehingga mempengaruhi emosi anak hingga ia meniru perilaku idolanya tersebut (Sitompul, 2016). Anakanak yang sedang dalam fase meniru akan mencari sosok ideal untuk dijadikan sebagai idola/model mereka. Beberapa contoh idola yang dapat dijadikan teladan bagi anak antara lain adalah orang tua, guru, teman sebaya, hingga tokoh/karakter (nyata ataupun fiksi) yang ia temukan di media eksternal yang menjadi tren di era modern seperti buku, film, musik, dan lain-lain.

\section{Penerapan Pendidikan Karakter di Era Modern}

Seiring kemajuan teknologi dan perkembangan zaman, 
penerapan pendidikan karakter kini tidak hanya berlangsung di sekolah atau di rumah saja. Di era modern seperti saat ini, pendidikan karakter dapat dimasukkan ke berbagai media eksternal yang dekat dengan anak, salah satunya dengan menggunakan animasi. Anak-anak sangat menyukai animasi yang ditayangkan di televisi maupun internet. Terkadang, mereka mengidolakan tokoh fiksi yang ada di dalam animasi tersebut. Menurut Anwas (2010), pesan tentang pendidikan karakter dapat dikemas melalui penokohan (dalam hal ini tokoh di animasi) dalam konteks sikap, pemikiran, perbuatan dan perkataannya (Anwas, 2010). Tokoh dalam animasi berpotensi untuk menjadi model yang akan ditiru oleh anak. Selain itu, Danny (2013) berpendapat bahwa pengalaman-pengalaman dari referensi permodelan yang didapat oleh anak (terlepas dari pengalaman positif/negatif), tentunya dapat membentuk dan memudahkan proses pencarian karakter si anak tersebut (Danny, 2013). Beliau juga berpendapat bahwa nilai-nilai yang terkandung dalam pesan yang dibawa oleh cerita, ternyata mampu disimpan dengan sangat baik di ingatan anak, bahkan dapat terbawa sampai anak tumbuh dewasa, untuk kemudian dijadikan sebagai referensi mereka saat dibutuhkan (misal dalam menyelesaikan masalah atau pengambilan keputusan).

Untuk memaksimalkan potensi animasi sebagai media pendidikan karakter, konten yang menjadi pesan utama dalam animasi tersebut juga perlu diperhatikan. Hyoscyamina (2011) memiliki beberapa cara yang bisa digunakan dalam proses pembentukkan karakter anak, salah satu di antaranya adalah dengan mengenalkan anak pada agama dan tuhannya (Hyoscyamina, 2011). Ajaran agama sebagai landasan pendidikan karakter merupakan hal yang esensial untuk ditanamkan pada anak-anak. Mengemas konten berupa ajaran agama ke dalam animasi merupakan cara yang bisa digunakan agar anak dapat meniru hal-hal baik dari sana. Setiap agama memiliki ajaran yang berkaitan dengan pendidikan karakternya masing-masing, begitu pula agama Hindu yang memiliki ajaran bernama Tri Kaya Parisudha.

\section{Tri Kaya Parisudha}

Nada Atmaja dkk. (2010) dalam Meliala dkk. (2018) menjelaskan bahwa terdapat tiga kerangka dasar dalam ajaran agama Hindu yang saling berkaitan satu sama lain, serta harus dihayati dan diamalkan untuk mencapai tujuan agama, yaitu "Tattwa" atau filsafat, "Susila" atau etika, dan "Upacara" atau ritual/yadnya (Meliala dkk., 2018). Kemudian, Suhardana (2007) menerangkan lebih lanjut bahwa aspek Tattwa adalah inti dari ajaran agama Hindu, aspek Susila adalah tata cara pelaksanaan atau pengamalan ajaran agama Hindu sehari-hari, dan aspek Upacara adalah ritual/yadnya yang merupakan pengorbanan suci kepada Tuhan (Suhardana, 2007). Pendidikan karakter dalam agama Hindu dilandaskan pada aspek Susila, karena karakter tersebut akan terbentuk dari bagaimana cara manusia mengamalkan ajaran agamanya dalam kehidupan sehari-hari.
Karakter manusia akan terlihat dari perilaku mereka dalam kehidupan sehari-hari. Singer (2015) menyebutkan bahwa perilaku tersebut dapat diamati dari tiga unsur, yaitu idep (implementasi dari pemikiran), sabda (implementasi dari perkataan), dan bayu (implementasi dari perbuatan) (Singer, 2015). Ketiga unsur tersebut dapat dibentuk dan diarahkan lewat ajaran agama Hindu dalam aspek Susila, yang salah satu ajarannya adalah Tri Kaya Parisudha.

\section{Definisi Tri Kaya Parisudha}

Sugita (2017) menjelaskan bahwa kalimat Tri Kaya Parisudha berasal dari bahasa kesusastraan Hindu kuno sanskerta, yang terdiri dari kata "Tri" yang berarti tiga, "Kaya" yang berarti perilaku, dan "Parisudha" yang berarti suci, baik, dan bersih (Sugita, 2017). Jika digabungkan, Tri Kaya Parisudha memiliki makna yaitu tiga perilaku manusia yang harus disucikan. Maksud dari disucikan adalah, ketiga perilaku manusia tersebut tidak boleh dinodai dengan perilaku yang tidak baik dan tidak benar. Suhardana (2007) juga menerangkan bahwa Tri Kaya Parisudha dapat dipahami dari "Tri Kaya" atau tiga sumber perilaku itu sendiri. Ketiga sumber tersebut adalah "manah" atau pikiran, "wak/waca" atau perkataan, dan "kaya" atau perbuatan (Suhardana, 2007). Ketiganya berfungsi secara berkesinambungan dan saling mempengaruhi satu dengan yang lainnya, serta berperan penting dalam membentuk karakter/pribadi seseorang. Subagia (2016) menjabarkan bagian-bagian Tri Kaya Parisudha yang terdiri atas "Manacika Parisudha" yaitu berpikir yang benar dan suci, "Wacika Parisudha" yaitu berkata yang baik dan benar, dan "Kayika Parisudha" yaitu berbuat yang baik dan benar (Subagia, 2016). Lebih lanjut, Jayendra (2018) menerangkan bahwa Manacika/pikiran harus dikendalikan agar selalu mengarah pada kebaikan, Wacika/perkataan hendaknya dituntun untuk selalu sopan dan benar, serta Kayika/perbuatan harus selalu dilandasi oleh dharma/kebaikan yang hakiki (Jayendra, 2014). Ketiga bagian Tri Kaya Parisudha sangat berpengaruh dalam membentuk karakter seseorang, oleh karena itu, ajaran ini sangat cocok untuk dijadikan landasan dalam pendidikan karakter pada anak-anak.

\section{Tri Kaya Parisudha sebagai Dasar Pendidikan Karak- ter}

Diantari (2017) berpendapat bahwa pemahaman Tri Kaya Parisudha perlu diberikan pada anak sebagai landasan utama dalam berfikir yang baik dan benar. Karena setiap apa yang akan dilakukan hendaknya diawali dengan pola pikir yang mulia, yang nantinya akan muncul perkataan yang sopan, hingga terjadinya sebuah perbuatan yang terpuji (Diantari, 2017). Dari situ terlihat bahwa pikiran memegang peranan penting dalam menentukan ucapan dan tindakan. Adnyana dan Citrawathi (2017) mengemukakan bahwa anak perlu menumbuhkan keselarasan antara apa yang dipikirkan, apa yang diucapkan, dan apa yang diperbuat, karena apabila antara ketiganya saling berbeda/tidak selaras dapat membuat anak jadi tidak jujur dengan dir- 
inya sendiri (Adnyana \& Citrawathi, 2017). Keselarasan antara pikiran, perkataan, dan perbuatan akan membentuk sifat integritas dan jati diri anak. Selain itu, Atmaja dan Subawa (2018) menjelaskan bahwa penerapan nilai-nilai yang terkandung dalam ajaran Tri Kaya Parisudha secara berkesinambungan dan terus-menerus, dapat melahirkan pola pikir yang positif (positive thinking), perkataan yang santun (polite communication), dan tingkah laku yang baik (good attitude) (Atmaja \& Subawa, 2018). Agar lebih mudah dipahami, dalam mengajarkan Tri Kaya Parisudha pada anak dapat menggunakan contoh-contoh yang konkret dalam kehidupan sehari-hari, yang dapat diterapkan ke media yang dekat dengan anak seperti cerita atau film animasi.

\section{Animasi Sebagai Media Pendidikan Karakter Anak}

Selain dari lingkungan keluarga, sekolah, dan pergaulan, perkembangan karakter anak juga dipengaruhi oleh media eksternal, contohnya media yang mereka baca atau tonton. Salah satu media yang dapat dijadikan sebagai sarana pendidikan karakter adalah film animasi. Menurut Langga dkk. (2019), film animasi adalah film yang dapat dikonsumsi oleh siapa saja, bersifat unik karena menggabungkan unsur naratif dan sinematik, serta memiliki konten yang tidak hanya menghibur namun juga mendidik (Langga dkk., 2019). Faktor menghibur dan mendidik adalah keunggulan dari media ini, yang mana sangat berpengaruh dalam menarik minat anak-anak. Setiawati (2016) mengemukakan beberapa manfaat media animasi dalam dunia pendidikan, yaitu (1) menunjukkan suatu objek dengan sebuah ide; (2) menerangkan konsep yang dianggap sulit; (3) menjelaskan konsep yang awalnya abstrak menjadi lebih konkret; dan (4) menunjukkan suatu langkah prosedural dengan lebih jelas (Setiawati, 2016). Animasi yang bersifat mendidik lebih sering ditujukan pada kalangan anakanak, karena mereka dapat menyerap materi/pesan yang mendidik tersebut dengan lebih mudah lewat bantuan media animasi.

Animasi yang dibuat khusus untuk anak pada dasarnya telah dirancang sedemikian rupa agar dapat diterima oleh anak-anak. Dari simpulan penelitian yang dilakukan oleh Pratiwi (2016), ada beberapa unsur yang dapat diperhatikan dalam merancang sebuah animasi untuk anak-anak, diantaranya adalah (1) karakter yang ditunjukkan merupakan anak-anak dan orang di sekitar mereka; (2) tema yang diangkat berkisar pada kehidupan anak sehari-hari; (3) latar yang ditampilkan merupakan latar tempat yang dekat dengan anak; (4) cerita dibuat dengan mengangkat masalah yang dapat diselesaikan oleh anak (sebab-akibat, urutan, hubungan, perbandingan, dll); (5) durasi animasi disesuaikan dengan kebutuhan; serta (6) penggunaan visual dan audio yang bersifat dinamis agar anak tidak bosan (Pratiwi, 2016). Animasi memiliki beberapa unsur yang terdapat di dalamnya, seperti karakter dan cerita. Kedua unsur tersebut dapat digunakan sebagai medium utama dalam menyampaikan pendidikan karakter lewat animasi.

\section{Pengaruh Unsur Karakter dan Cerita di Animasi}

Salah satu unsur animasi adalah karakter. Blair (1994) mengatakan bahwa dalam merancang dan mengembangkan karakter tidak hanya soal menggambar sosok, karakter tersebut harus memiliki bentuk, kepribadian, fitur, dan tingkah lakunya sendiri. Beliau menambahkan, kualitas sebuah karakter harus dipertimbangkan dengan matang, agar karakter tersebut dapat nampak hidup dan dapat dipercaya oleh penonton (Blair, 1994). Selain itu, Ruyattman dkk. (2013) berpendapat bahwa karakter sangat dibutuhkan dalam industri animasi edukatif, karena umumnya karakter yang menarik akan disenangi oleh anak, dan merangsung minat mereka dalam menyimak serta meresapi pembelajaran yang disampaikan di cerita animasi tersebut (Ruyattman dkk., 2013). Karakter/tokoh sering menjadi unsur utama yang menarik minat anak dalam menonton animasi. Terkadang karakter/tokoh tersebut dijadikan model/teladan oleh anak-anak. Karakter dalam animasi biasanya bersifat fiksi dan dapat berwujud manusia, hewan, atau makhluk/objek yang dihidupkan. Dalam sebuah penelitian yang dilakukan oleh Alifiryan (2019), diketahui bahwa faktor pengalaman yang dimiliki anak sangat berpengaruh terhadap karakter fiksi yang mereka suka. Anak-anak cenderung menyukai karakter fiksi yang memiliki beberapa unsur kesamaan dengan dirinya (seperti kesamaan warna favorit, hobi, sifat, dll) (Alifiryan, 2019). Pengalaman anak dan faktor kesamaan adalah kunci dalam membuat sebuah tokoh/karakter dalam animasi yang dapat disukai anak-anak.

Selain karakter, dalam setiap film animasi selalu ada narasi/ cerita yang diangkat. Wright (2013) menerangkan bahwa pada dasarnya, naskah animasi menggunakan 'three-act structure' atau struktur 3 babak, yaitu 'act 1 ' yang berakhir setelah masalah diatur, 'act 2'yang berakhir sebelum klimaks, dan 'act 3' yang merupakan resolusi dari cerita keseluruhan. Beliau juga berpendapat bahwa sebuah cerita hendaknya memiliki nilai/pesan utama yang ingin disampaikan, hal ini bertujuan agar penonton dapat memahami hubungan antar manusia dan dunia di sekitarnya (Wright, 2013). Animasi untuk anak-anak biasanya memiliki cerita yang telah dibuat secara spesifik untuk mereka. Huck dkk (1987) dalam Nurgiyantoro (2004) menerangkan bahwa salah satu karakteristik cerita anak adalah di mana kandungan konten yang jumlahnya dibatasi dan telah disesuaikan dengan cakupan psikologi dan emosional anak (Nurgiyantoro, 2004). Kedua cakupan tersebut sangat krusial agar membuat anak dapat memahami pesan/makna dari cerita tersebut. Menurut Nurgiyantoro (2010), jenis cerita anak yang berbentuk seperti sejarah, fabel, fiksi, biografi, atau dongeng, biasanya mengangkat tokoh-tokoh yang bisa dijadikan sebagai model kehidupan bagi anak (Nurgiyantoro, 2010). Karakter dan cerita dalam animasi merupakan dua unsur yang mempengaruhi perkembangan karakter anak. Hal tersebut disebabkan oleh adanya kaitan antara animasi dengan proses meniru anak. 


\section{Animasi dan Kaitannya dengan Proses Meniru Anak} Adak (2004) dan Middleton \& Vanterpool (1999) dalam İvrendi dan Özdemir (2010) mengatakan bahwa anak-anak mungkin tidak terlalu dapat membedakan antara realita dan fantasi, oleh karena itu mereka memiliki kecenderungan untuk meniru apa yang mereka lihat dalam kartun/ animasi (İvrendi \& Özdemir, 2010). Berdasarkan penelitian yang dilakukan oleh Rinayanti dkk. (2016), diketahui adanya ikatan emosional anak pada karakter dalam animasi yang ditunjukkan dengan perubahan sikap, perilaku dan ekspresi anak. Keterikatan emosional tersebut dituangkan dalam proses meniru karakter yang anak tonton di animasi. Beberapa contohnya seperti meniru gaya/gerak tokoh, meniru lagu yang dinyanyikan tokoh, hingga meniru adegan yang diperagakan tokoh (Rinayanti dkk., 2016). Hal tersebut senada dengan yang dikemukakan oleh Nurgiyantoro (2010), bahwa penonton dapat terbawa arus cerita berkat keterlibatan pikiran (kognitif) dan emosi (afektif), sehingga mereka dapat turut merasakan apa yang tokoh dalam cerita tersebut rasakan, berkat berkembangnya rasa estetis dan imajinasi mereka (Nurgiyantoro, 2010). Anak-anak yang terasah imajinasinya akan merasakan ikatan emosional yang lebih kuat pada karakter atau cerita yang disampaikan dalam sebuah animasi.

Selain karakter dalam animasi, anak-anak juga dapat terpengaruh oleh cerita yang dibawakan oleh animasi tersebut. Menurut Munaris (2011), sebuah karya sastra dalam bentuk cerita memiliki keunggulan di mana ia bersifat tidak hanya dapat menghibur namun juga berguna dan memberikan sebuah makna (dulce et utile), sehingga sangat layak untuk dijadikan bahan ajar untuk pendidikan karakter (Munaris, 2011). Nurgiyantoro (2004) menjelaskan bahwa ketika suatu citra kehidupan ditampilkan di sebuah cerita, penonton akan mulai mengkonstruksi imajinasi dalam pikiran mereka, dengan menggabungkan berbagai pengalaman-pengalaman yang dimiliki. Tidak jarang, mereka akan mengkomparasi model kehidupan di cerita dengan kehidupan mereka sendiri (Nurgiyantoro, 2004). Ketika anak belum memiliki cukup pengalaman dalam dirinya, animasi dapat dijadikan sebagai rujukan yang akan menjadi pengalaman barunya. Pengalaman yang tercipta itu dijadikan oleh anak sebagai pembelajaran dalam membentuk karakternya, melalui proses meniru/imitasi.

\section{Pembelajaran dengan Animasi Melalui Proses Meniru} Selain sebagai media hiburan, animasi juga digunakan untuk menunjang proses pembelajaran. Dalam dunia pendidikan dikenal sebuah teori taksonomi Bloom, yang menerangkan beberapa tingkatan proses pembelajaran dalam aspek kognitif. Di tingkat pertama/dasar dari taksonomi Bloom adalah mengingat (remembering), yaitu sebuah proses mengambil pengetahuan yang relevan dari memori. Churches (2010) menjelaskan bahwa dalam implementasi dari teori Bloom yang punya bentuk beragam sebenarnya mewakili proses pembelajaran, seperti "sebelum bisa memahami sebuah konsep, kita harus bisa mengingatnya," lalu "sebelum bisa menerapkan konsep tersebut, kita harus bisa memahaminya", dan seterusnya (Churches, 2010). Ada beberapa cara agar anak-anak dapat mengingat materi pembelajaran. Tulasi (2010) menggunakan contoh kegiatan 'mengulang' dalam tahap mengingat (remember), karena dengan mengulang, manusia akan mencoba mengungkapkan kembali berbagai makna dari obyek yang telah/sedang berhadapan dengannya, dengan menggunakan kata atau kalimat yang merepresentasikan keseluruhan ingatan yang dimilikinya (Tulasi, 2010). Dengan mengulangi materi pembelajaran yang disampaikan dalam animasi, anak-anak dapat terasah ingatannya terhadap materi tersebut.

Cara mengingat dengan kegiatan mengulang dapat diterapkan di media animasi, terutama untuk anak-anak yang sedang dalam proses meniru. Penelitian yang dilakukan oleh Marlianingsih (2016) menunjukkan adanya peningkatan penggunaan kosa kata bahasa Inggris yang diajarkan dengan cara mengulang dan meniru lewat bantuan animasi. Di penelitian tersebut, anak-anak menonton \& mendengarkan kosa kata dalam animasi selama 3 kali, lalu mereka diminta untuk mengulang dan meniru kosa kata tersebut hingga dapat mengucapkannya dengan benar (Marlianingsih, 2016). Penelitian lainnya dilakukan oleh Mustanzier (2016) yang menerangkan bahwa animasi juga berpengaruh terhadap perilaku komunikasi anak. Dalam penelitiannya diungkapkan bahwa ketika anak menonton animasi "Upin dan Ipin" yang ditayangkan secara berulang-ulang di televisi, maka menyebabkan anak dapat meniru logat dan gaya bahasa melayu yang digunakan di animasi tersebut, bahkan hingga menerapkannya di kehidupan sehari-hari mereka (Mustanzier, 2016). Dari kedua penelitian tersebut, dapat disimpulkan bahwa pemanfaatan media animasi secara berulang-ulang dapat memicu proses meniru anak, sehingga berpengaruh pada perilaku dan pengetahuan mereka.

\section{SIMPULAN}

Pendidikan karakter sangat penting untuk diberikan pada anak sejak dini, terutama saat ia berada dalam fase imitasi. Di fase ini, anak belajar meniru perangai seperti cara bicara dan cara bersikap yang diambil dari model yang diteladani. Meniru dengan keteladanan mengajarkan anak untuk mengembangkan moral, sosial dan spiritual mereka. Hasil pembelajaran dari imitasi tersebut nantinya akan ia ingat kembali untuk diulangi di kehidupannya sehari-hari, hingga akan membentuk karakter anak tersebut. Salah satu landasan pendidikan karakter dalam Hindu adalah ajaran Tri Kaya Parisudha. Ajaran ini sangat penting untuk dipahami dan diamalkan di kehidupan sehari-hari. Ketiga bagian dari Tri Kaya Parisudha yaitu Manacika, Wacika, dan Kayika sangat baik untuk diajarkan pada anak dalam membentuk sifat integritas dan jati dirinya. Keselarasan antara pikiran, ucapan, dan tindakan agar selalu berada di jalan yang baik dan benar adalah hal utama yang diajarkan 
di Tri Kaya Parisudha.

Ketika menyampaikan pendidikan karakter pada anakanak, kita dapat menggunakan pendekatan keteladanan, yaitu sebuah proses meniru perilaku yang diperagakan oleh model/idola yang disukai mereka. Di era modern, penerapan pendidikan karakter bisa dilakukan dengan bantuan media eksternal seperti animasi. Konsep pendidikan karakter yang dikemas lewat tokoh animasi dapat dijadikan model/idola oleh anak untuk ditiru. Selain itu, nilai yang terkandung lewat cerita di animasi juga dapat terbawa sampai anak tumbuh dewasa, dan dijadikan referensi olehnya saat dibutuhkan. Animasi sendiri sudah sering dijadikan sebagai media pembelajaran, karena sifatnya yang mendidik dan menghibur. Anak cenderung menyukai karakter animasi yang punya unsur kesamaan dengannya berdasarkan pengalaman yang ia miliki. Adanya ikatan emosional anak pada karakter animasi menyebabkan anak meniru gaya/gerak karakter tersebut, hingga turut merasakan apa yang dirasakan karakter itu. Selain itu, cerita dalam animasi juga memberikan pengalaman baru bagi anak untuk dijadikan pembelajaran dalam pembentukkan karakternya. Sebagai media pembelajaran, animasi dapat menunjang aspek kognitif anak dengan cara mengingat apa yang ia dapat di animasi tersebut, untuk kemudian ditiru agar dapat membentuk karakter mereka.

\section{DAFTAR RUJUKAN}

Adnyana, P. B., \& Citrawathi, D. M. (18 November 2017), "Model Pendidikan Karakter Berbasis Tri Kaya Parisudha Terintegrasi dalam Pembelajaran di Sekolah Dasar", dalam Seminar Nasional Riset Inovatif 52017 Universitas Pendidikan Ganesha, di Inna Grand Bali Beach.

Akbar, M. (Februari 2019), "Mendidik Siswa dengan Prinsip Keteladanan", dalam Jurnal Teknologi Pendidikan Madrasah, II/01, Institut Agama Islam AL Mawaddah Warrahmah Kolaka, Sulawesi Tenggara.

Alifiryan, I. A. (4 September 2019), "Karakter Visual sebagai Cerminan Konsep Diri Anak Generasi Z", dalam Seminar Nasional Seni, Kriya dan Desain (Sandyakala) 2019 Institut Seni Indonesia Denpasar, di Gedung Citta Kelangen.

Anwas, O. M. (Oktober 2010), "Televisi Mendidik Karakter Bangsa: Harapan dan Tantangan", dalam Jurnal Pendidikan dan Kebudayaan, XVI/9, Badan Penelitian dan Pengembangan Kementerian Pendidikan dan Kebudayaan, Jakarta.

Atmaja, I. K. M., \& Subawa, N. S. (September 2018), "Human Resource Development Model Based on Local Wisdom Tri Kaya Parisudha in Dealing with Globalization", dalam Jurnal Manajemen Bisnis, XV/3, Universitas Pendidikan Nasional, Bali.
Bandura, A. (April 1963), "The Role of Imitation in Personality Development", dalam The Journal of Nursery Education, XVIII/3, National Association for the Education of Young Children, Amerika Serikat.

Blair, P. (1994), Cartoon Animation (Collectors edition), Walter Foster Publishing, Laguna Hills.

Churches, A. (2010), Bloom 's digital taxonomy, Australian School Library Association NSW Incorporated. Diunduh 8 Juli 2019 dari http://burtonslifelearning.pbworks.com/f/ BloomDigitalTaxonomy2001.pdf

Dahlia, T., Safiah, I., \& Z, S. (Desember 2017), "Pengaruh Penggunaan Handphone Terhadap Perkembangan Karakter Anak pada Usia Sekolah Dasar di SDN 20 Kota Banda Aceh", dalam Jurnal Ilmiah Mahasiswa Pendidikan Guru Sekolah Dasar, II/4, Universitas Syiah Kuala, Banda Aceh.

Danny, D. E. (Juni 2013), Pembentukan Karakter Anak Melalui Kegiatan Mendongeng, dalam HUMANIKA, XVII/1, Universitas Diponegoro, Semarang.

Hurlock, E. B. (1980), Developmental Psychology: A Life-Span Approach atau Psikologi perkembangan: Suatu pendekatan sepanjang rentang kehidupan, terjemahan Istiwidayanti, R.M. Sijabat, \& Soedjarwo (1990), Erlangga, Jakarta.

Hyoscyamina, D. E. (Oktober 2011), Peran Keluarga dalam Membangun Karakter Anak, dalam Jurnal Psikologi, $\mathrm{X} / 2$, Universitas Diponegoro, Semarang.

İvrendi, A., \& Özdemir, A. A. (Januari 2010), Mothers' Evaluation of Cartoons' Influence on Early Childhood Children, dalam Procedia - Social and Behavioral Sciences, II/2, Elsevier Ltd., Amsterdam.

Jayendra, P. S. (Oktober 2014), Peranan Keluarga, Sekolah, dan Masyarakat dalam Implementasi Pendidikan Tri Kaya Parisudha sebagai Landasan Pembentukan Karakter Generasi Muda, dalam Prosiding Seminar Nasional Peran Agama dan Budaya Dalam Membentuk Karakter Remaja Dalam Kehidupan Multikultur, Institut Hindu Dharma Negeri Denpasar, Denpasar.

Jelantik, I.G.L. (Mei 2016), Membangun Karakter Berbasis Pendidikan Seni Budaya di Sekolah, dalam Mudra Jurnal Seni Budaya, XXXI/2, Institut Seni Indonesia Denpasar, Denpasar.

Labiadh, L., \& Ramanantsoa, M.-M. (Agustus 2014), Children's Imitation with Varied Demonstration and Reproduction Delays, dalam Procedia - Social and Behavioral Sciences, CXL, Elsevier Ltd., Amsterdam. 
Langga, F. H., Ahmad, H. A., \& Mansoor, A. Z. (Agustus 2019), Web Series Animasi Nussa sebagai Media Pendidikan Islami pada Anak, dalam Jurnal Komunikasi Visual Wimba, X/1, Institut Teknologi Bandung, Bandung.

Maradewa, R. (4 Mei 2019), Catatan KPAI di Hardiknas: Kasus Anak Bully Guru Meningkat Drastis. http://www. kpai.go.id/berita/catatan-kpai-di-hardiknas-kasus-anakbully-guru-meningkat-drastis

Marlianingsih, N. (Agustus 2016), Pengenalan Kosa Kata Bahasa Inggris Melalui Media Audio Visual (Animasi) pada PAUD, dalam Faktor Jurnal Ilmiah Kependidikan, III/2, Universitas Indraprasta PGRI, Jakarta.

Meliala, J. B., Sujana, I. M., \& Arsana, A. A. M. P. (Mei 2018), Pola Pembelajaran Nilai-Nilai Etika Agama Hindu pada Peserta Didik di Pasraman Raksa Bhuana Medan, dalam Jurnal Penelitian Agama Hindu, II/1, Insitut Hindu Dharma Negeri Denpasar, Denpasar.

Mustanzier, P. A. (Agustus 2016), Penggunaan Gaya Bahasa Melayu dalam Tayangan Film Kartun Animasi Upin dan Ipin pada Perilaku Komunikasi Anak di SD Negeri 1 Poasia Kendari, dalam Jurnal Ilmu Komunikasi UHO : Jurnal Penelitian Kajian Ilmu Komunikasi Dan Informasi, I/2, Universitas Halu Oleo, Kendari.

Nabavi, R. T. (1 Januari 2012), Bandura's Social Learning Theory \& Social Cognitive Learning Theory. https://www. researchgate.net/publication/267750204_Bandura's_Social_Learning_Theory_Social_Cognitive_Learning_Theory

Nurgiyantoro, B. (Juni 2004), Kontribusi Sastra Anak dalam Pembentukan Kepribadian Anak, dalam Jurnal Cakrawala Pendidikan, XXIII/2, Universitas Negeri Yogyakarta, Yogyakarta.

Nurgiyantoro, B. (Mei 2010), Sastra Anak dan Pembentukan Karakter, dalam Jurnal Cakrawala Pendidikan, XXIX/3, Universitas Negeri Yogyakarta, Yogyakarta.

Pratiwi, Y. (Oktober 2016), Film Animasi Cerita dengan Konteks Multibudaya untuk Mendukung Pengembangan Kekritisan Penalaran Anak Usia SD, dalam LITERA, XV/2, Universitas Negeri Yogyakarta, Yogyakarta.

Rakhmawati, I. (Juni 2015), Peran Keluarga dalam Pengasuhan Anak, dalam KONSELING RELIGI: Jurnal Bimbingan Konseling Islam, VI/1, Institut Agama Islam Negeri Kudus, Kudus.

Rinayanti, Ahmad, A., \& Maidiyah, E. (Agustus 2016), Perkembangan Sosial Emosional Anak yang Menonton Film Animasi di TK Idaman Hati Kecamatan Sawang Aceh Utara, dalam Jurnal Ilmiah Mahasiswa Pendidikan
Anak Usia Dini, I/1, Universitas Syiah Kuala, Banda Aceh.

Ruyattman, M., Waluyanto, H. D., \& Zacky, A. (Juli 2013), Perancangan Buku Panduan Membuat Desain Karakter Fiksi Dua Dimensi secara Digital, dalam Jurnal DKV Adiwarna, I/2, Universitas Kristen Petra, Surabaya.

Setiawati, L. (Juni 2016), Penerapan Media Animasi sebagai Inovasi dalam Pembelajaran di Sekolah Dasar Ciledug 2 Kecamatan Ngamprah Kabupaten Bandung Barat, dalam Jurnal Penelitian Pendidikan, XVI/1, Universitas Pendidikan Indonesia, Bandung.

Singer, I. W. (2015), Pendidikan Karakter Berlandaskan Tri Kaya Parisudha, PT. Pustaka Manikgeni, Denpasar.

Sitompul, H. (Januari 2016), Metode Keteladanan dan Pembiasaan dalam Penanaman Nilai-Nilai dan Pembentukan Sikap pada Anak. dalam Jurnal Darul 'Ilmi, IV/1, Institut Agama Islam Negeri Padangsidimpuan, Padangsidimpuan.

Subagia, I. N. (Februari 2016), Etika sebagai Dasar Pengendalian Diri Manusia, dalam Jurnal Penjaminan Mutu, I/1, Institut Hindu Dharma Negeri Denpasar, Denpasar.

Sudrajat, A. (Oktober 2011), Mengapa Pendidikan Karakter?, dalam Jurnal Pendidikan Karakter, I/1, Universitas Negeri Yogyakarta, Yogyakarta.

Sugita, I. W. (Mei 2017), Membentuk Karakter Anak Usia Dini Melalui Tri Kaya Parisudha, dalam Prosiding Seminar Nasional Anak Usia Dini (SEMADI) 2, I/I, Institut Hindu Dharma Negeri Denpasar, Denpasar.

Suhana, M. (10-11 Oktober 2017), "Influence of Gadget Usage on Children's Social-Emotional Development", dalam International Conference of Early Childhood Education (ICECE 2017) Universitas Negeri Padang, di Hotel Pangeran Beach.

Suhardana, K. M. (2007), Tri Kaya Parisudha-Bahan Kajian Untuk Berpikir Baik, Berkata Baik dan Berbuat Baik, Paramita, Surabaya.

Tulasi, D. (Oktober 2010), Merunut Pemahaman Taksonomi Bloom: Suatu Kontemplasi Filosofis, dalam $\mathrm{Hu}$ maniora Binus, I/2, Universitas Bina Nusantara, Jakarta. Wright, J. A. (2013), Animation Writing and Development: From Script Development to Pitch. Routledge, London.

Zuchdi, D. (Mei 2010), Pengembangan Model Pendidikan Karakter Terintegrasi dalam Pembelajaran Bidang Studi di Sekolah Dasar, dalam Jurnal Cakrawala Pendidikan, I/3, Universitas Negeri Yogyakarta, Yogyakarta. 